JURNAL ILMIAH KOMPUTER GRAFIS, Vol.14, No.1, Juli 2021, pp. 25 - 36

p-ISSN : 1979-0414(print)

e-ISSN : 2621-6256 (online)

http://journal.stekom.ac.id/index.php/pixel

\title{
Penerapan Digital Marketing Sebagai Strategi Pemasaran Ukm Rempeyek Nok Uus dengan Video Cinematic Didukung Motion Grafis
}

\author{
Rahmat Gunawan', Rini Malfiany², Hamdan Yosep Pane ${ }^{3}$ \\ ${ }^{1}$ STMIK Rosma \\ Jl. Kertabumi No.62 Karawang Barat 41311Karawang, Jawa Barat, email : rahmat@rosma.ac.id \\ ${ }^{2}$ STMIK Rosma \\ Jl. Kertabumi No.62 Karawang Barat 41311Karawang, Jawa Barat, email:rini.malfiany@dosen.rosma.ac.id \\ ${ }^{3}$ STMIK Rosma \\ Jl. Kertabumi No.62 Karawang Barat 41311Karawang, Jawa Barat, email : hamdan.pane@mhs.rosma.ac.id
}

\begin{tabular}{|c|c|}
\hline ARTICLE INFO & ABSTRACT \\
\hline $\begin{array}{l}\text { Article history: } \\
\text { Received } 30 \text { Mei } 2021 \\
\text { Received in revised form } 2 \text { Juni } 2021 \\
\text { Accepted } 10 \text { Juni } 2021 \\
\text { Available online july } 2021\end{array}$ & $\begin{array}{l}\text { Designing story scenarios for the Rempeyek Nok } \\
\text { Uus UKM profile video, Making videos by } \\
\text { recording, editing, and adding effects, Implementing } \\
\text { marketing strategies with digital marketing } \\
\text { techniques on social media. To obtain the necessary } \\
\text { data, the things that must be done are interviews, } \\
\text { observations, and documentation. So that they can } \\
\text { get a mature concept for video production, the } \\
\text { reference is from the information obtained during } \\
\text { observations and interviews. Rempeyek Nok Uus } \\
\text { has become a typical souvenir from Karawang and } \\
\text { snacks or snacks from the Karawang area. } \\
\text { Optimizing the digital platform as a place to order } \\
\text { products so that it is easy for people to order, Active } \\
\text { in social media, especially Instagram and Facebook } \\
\text { in advertising products, Invite Instagram celebrities } \\
\text { to work together who already have more than } 10 \mathrm{~K} \\
\text { followers to promote products to customers. }\end{array}$ \\
\hline
\end{tabular}

Keywords: Cinematic Video, Digital Marketing, Products, Rempeyek

\section{Introduction}

Pesatnya kemajuan dunia teknologi dan informasi, hal tersebut menjadikan internet sebagai media komunikasi yang banyak diminati oleh masyarakat. Sehingga mengakibatkan perubahan komunikasi konvensional menjadi modern dan menjadi serba digital. Kemajuan ini pun semakin meluas semenjak telepon seluler sebagai media internet yang banyak digunakan masyarakat luas. Dari telepon seluler atau smartphone memberikan banyak fasilitas seperti sms, chatting, e-mail, browsing, dan juga fasilitas media sosial seperti instagram, twitter, facebook, youtube, dan lain-lain. Pada berkembangnya kemajuan teknologi, hal tersebut berdampak hampir rata-rata penduduk di Indonesia menggunakan smartphone sebagai sarana informasi. Dengan kemajuan teknologi ini dapat dimanfaatkan dalam bidang pemasaran yang akan membuat cost dalam biaya promosi menjadi rendah dengan hasil yang luar biasa. Dengan kemajuan teknologi, bahwa jarak bukan sebagai penghalang lagi, sangat jauh berbeda dengan cara konvensional yang dulu sangat sulit dan memerlukan cost yang banyak dalam memasarkan produk. Sosial media 
adalah merupakan media sosialisasi dan interaksi, yang dapat menarik perhatian orang untuk melihat tautan yang berisi tentang informasi mengenai suatu barang dan jasa. Contohnya yang lagi trend di zaman sekarang adalah instagram salah satu platform media sosial terbesar yang banyak digunakan masyarakat terutama kalangan remaja. Dimana para user dapat mengedit dan memposting foto atau video ke beranda dan jejaring sosialnya.

Ukm Nok uus berdiri sejak tahun 2009, mekanisme yang dilakukan selama ini dengan memasarkan produk secara konvensional ke outlet-outlet atau menitipkan produk di warungwarung makan, kantin rumah sakit, minimarket, dan kios-kios kecil lainnya. Dengan kemajuan zaman owner belum bisa beradaptasi dengan berkembangnya teknologi, sehingga menyulitkan untuk mempromosikan produk lewat media sosial. Kendala dari owner tersebut adalah kurangnya pengetahuan untuk kemasan promosi agar dapat di iklan kan lewat sosial media.

Nok uus adalah owner dari brand "Rempeyek Nok Uus", memiliki 5 karyawan yang membantu dalam proses produksi rempeyek. Rempeyek nok uus memiliki macam-macam varian rasa, antara lain rasa kacang kedelai, teri, dan kacang tanah. Konsumen rempeyek nok uus sampai saat ini udah cukup meluas, nok uus juga menjualkan produknya di supermarket ternama seperti carefour dan transmart.

Teknik pengambilan data yang dilakukan penulis dengan cara observasi langsung ke lapangan dan mewawancarai owner rempeyek nok uus dan suami owner yang bernama Bpk Asep H Syamsudin.

Berdasarkan latar belakang yang diuraikan diatas tersebut, maka penulisan mengangkat judul "Penerapan Digital Marketing Sebagai Strategi Pemasaran Ukm Rempeyek Nok Uus Dengan Video Cinematic Didukung Motion Grafis".

\section{Research Method}

\section{a. Strategi}

Menurut (Aris Kurniawan 2020) Strategi adalah ilmu dan seni menggunakan semua sumber daya bangsa untuk melaksanakan kebijaksanaan tertentu diperang dan damai. Ilmu dan seni memimpin bala tentara untuk menghadapi musuh dalam perang, dalam kondisi yang menguntungkan, sebagai komandan memang mengusai betul seorang perwira di medan perang serta rencana yang cermat mengenai kegiatan untuk mencapai sasaran khusus, tempat yang baik menurut siasat perang.[1]

Strategi adalah pendekatan secara keseluruhan yang berkaitan dengan pelaksanaan gagasan, perencanaan, dan eksekusi sebuah aktivitas dalam kurun waktu tertentu. Di dalam strategi yang baik terdapat koordinasi tim kerja, memiliki tema, mengidentifikasi faktor pendukung yang sesuai dengan prinsip - prinsip pelaksanaan gagasan secara rasional, efisien dalam pendanaan, dan memiliki taktik untuk mencapai tujuan secara efektif.

\section{b. Langkah - langkah Strategi Pemasaran}

Menurut (Ardiansyah, Gumelar 2020) Langkah-langkah strategi pemasaran bisnis menurut kapasitasnya Manajemen pemasaran yaitu, sebagai segmentasi pasar tindakan mengidentifikasikan dan membentuk kelompok pembeli atau konsumen secara terpisah. Upaya untuk mengelompokkan pasar dalam karakteristik yang homogeny. Segmentasi pasar memungkinkan perusahaan beroperasi dengan sumber daya terbatas karena produksi massal dan iklan massal yang tidak diperlukan. Untuk menciptakan segmentasi pasar, perusahaan harus dapat melihatnya berdasarkan targeting dan positioning.[2]

\section{c. Teori Promosi}

Menurut (Widayati, Aris 2019) Teori promosi adalah perkenalan dalam rangka memajukan usaha dagang. Promosi merupakan salah satu jenis komunikasi yang sering dipakai oleh pemasar. Sebagai salah satu elemen bauran promosi, promosi penjualan merupakan unsur penting dalam kegiatan promosi produk. Promosi adalah upaya untuk memberitahukan atau menawarkan produk atau jasa dengan tujuan menarik calon konsumen untuk membeli atau

JURNAL ILMIAH KOMPUTER GRAFIS Vol. 14, No. 1, Juli $2020: 25-36$ 
mengkonsumsinya. Dengan adanya promosi produsen atau distributor mengharapkan kenaikannya angka penjualan.[3]

d. Video

Menurut (Arsyad 2020) Video adalah teknologi untuk menangkap, merekam, memproses, mentransmisikan dan menata ulang gambar bergerak. biasanya menggunakan film seluloid, sinyal elektronik atau media digital. Video juga bisa dikatakan sebagai gabungan gambar gambar mati yang dibaca berurutan dalam suatu waktu dengan kecepatan tertentu. Gambar gambar yang digabung tersebut dinamakan frame dan kecepatan pembacaan gambar disebut dengan frame rate, dengan satu fps.[4]

\section{e. Teori Pemasaran / Marketing}

Menurut (Fauzi Y 2015) pemasaran adalah penilaian strategi pemasaran, jasa, fungsi, dan hasilnya. Pengusaha yang sudah mengenal bahwa pemasaran merupakan faktor penting untuk mencapai sukses perusahaan, khususnya dalam hal memasarkan produknya.[5] Setiap perusahaan akan berusaha keras untuk mengetahui adanya cara falsafah baru yang terlibat dalam kegiatan pemasaran yang disebut dengan konsep pemasaran, dan jasa dari produsen ke konsumen, yang secara efektif menyesuaikan penawaran dan permintaan serta mencapai tujuan masyarakat. Menurut Kotler dan Amstrong dalam bukunya yang berjudul prinsip - prinsip pemasaran mengatakan bahwa pemasaran sebagai proses sosial dalam manejerial dimana pribadi atau organisasi memperoleh apa yang mereka inginkan dan butuhkan, melalui penciptaan dan pertukaran nilai dengan orang lain. Adapun pemasaran dilakukan secara online ialah online video marketing.

Video Marketing adalah sebuah metode baru dalam online marketing dengan memanfaatkan media video. Video marketing adalah opsi terbaik untuk online marketing. Karena dengan video marketing selain terkonsep dan menarik, video marketing dapat menampilkan gambar dan audio secara bersamaan dan memiliki dampak positif bagi yang melihat video tersebut. Selain itu video juga dapat diupload di berbagai media sosial, contohnya, facebook, instagram, dan youtube.

Istilah lain video marketing adalah suatu metode pemasaran baru dalam marketing online yang menggunakan media video. Video marketing merupakan strategi terbaik pemasaran bisnis / brand di era digital saat ini. Karena jika video marketing telah terkonsep dan menarik hasilnya, video ini bisa menampilkan gambar dan audio secara bersamaan yang mudah diserap audiens, sekaligus mengubah audiens menjadi customer.

\section{f. Editing Video}

Menurut (Sugihartini 2021) Editing adalah Merupakan Proses menyusun file - file hasil produksi sesuai dengan skenario dan alur cerita yang telah dibuat.[6] Beberapa tahapan detailnya dijelaskan pada bagian - bagian berikut ini :

1) Roughcut

Dimaknai sebagai penggabungan gambar dari scene - scene sesuai naskah dan yang telah direkam dalam proses produksi film. Proses ini membutuhkan diskusi dengan sutradara mengenai beberapa hal diantaranya visualisasi terbaik.

2) Answer Print

Editor bersama dengan sound director beserta sutradara memproses draft editing sampai dengan sound lock. Pada tahapan ini gambar dan suara telah dikunci.

3) ADR (Automatic Dialogue Replacement)

Merupakan proses penebalan / pengganti dialog pada dialog - dialog yang kurang jelas yang dilakukan oleh aktor pada saat shooting. Sehingga ketika memasuki tahapan editing ada beberapa bagian suara yang kurang jelas, yang harus dilakukan perbaikan.

4) Foley 
Merupakan proses penambahan sound effect pada video, misalnya membutuhkan suara jangkrik, ayam berkokok, atau derit pintu terbuka dan lain sebagainya.

5) Secure Music

Diartikan sebagai music yang aman. Bukan menggunakan musik - musik yang beredar di pasaran dan mengandung hak cipta. Jadi secure music dalam pembuatan film pendek disini juga mengidealkan adanya musik yang original, musik - musik yang baru hasil penciptaan dari seorang komposer musik.

6) Mixing

Penggabungan beberapa jenis unsur suara yang telah dimiliki, dialog, suara latar, ADR, sound effect, dan musik yang didapatkan sebuah harmon dalam setiap scene.

\section{g. Video Cinematic}

Menurut (Muhammad Falahunaufal 2020) Sinematik akar katanya berasal dari terminologi Yunani, "menulis dengan gerak". Sinematik memiliki unsur dalam film yang bisa dilihat dan didengar dengan tujuan mengantarkan cerita. Sinematik bukan sekedar mengambil gambar, tapi ada gagasan dibaliknya, bagaimana cerita dialirkan, bagaimana dramatik dibangun, ada aksi, pembentukan makna dan bentuk-bentuk komunikasi lainnya.[7]

\section{h. SEO ( Search Engine Optimization)}

Menurut google, sebanyak $62 \%$ pengguna internet di Indonesia mengakses online shop dan data menunjukkan bahwa $93 \%$ traffic untuk bisnis online datang melalui seacrh engine. Hal ini menunjukkan bahwa setelah kita memiliki website yang baik, maka search engine akan mendatangkan pengunjung ke website kita. SEO adalah proses untuk mengoptimalkan situs web kita supaya tampil lebih baik di halaman mesin pencari. Tentunya kita ingin website kita supaya tampil dihalaman pertama bahkan di posisi paling atas mesin pencari google. Beritkut adalah manfaat dari SEO :

1. Menaikan ranking website kita di mesin pencari khususnya google.

2. Mendapatkan lebih banyak trafik dari calon pelanggan yang sudah lebih tertarik dengan bisnis kita.

3. Trafik gratis $24 / 7$.

4. Meningkatkan kesadaran merek bisnis kita dan mendapatkan kepercayaan lebih dari calon pelanggan.

5. Membantu mendapatkan calon pelanggan sehingga membantu mengembangkan bisnis kita.

\section{i. Marketing Online}

Menurut (Laili Hidayati 2018), Marketing online adalah bentuk usaha kita dalam memasarkan atau memperkenalkan brand kita melalui internet. Zaman sekarang, siapapun bisa dan boleh memasarkan apa saja melalui internet. Sehingga, kita juga bisa menawarkan apapun melalui internet supaya produk yang kita pasarkan dapat dibeli oleh orang banyak.[8]

Cara pemasaran melalui internet kini sangat ditekuni oleh siapapun terutama oleh para pelaku usaha, karena dengan cara ini biaya iklan pun relatif murah dan tidak menekan biaya pemasaran yang begitu mahal. Cukup terkoneksi internet saja kita sudah bisa melakukan pemasaran melalui internet ini. Tujuan dari marketing online ini adalah untuk menjangkau sebanyak-banyaknya target customer secara efisien, personal dan relevan

\section{j. Data Pelanggan}

Menurut (Setyowati 2017) Data Pelanggan adalah orang yang menjadi pembeli produk yang telah dibuat dan dipasarkan oleh sebuah perusahaan, dimana orang ini bukan hanya sekali membeli tapi sudah berulang-ulang.[9]

\section{k. Media Sosial}

JURNAL ILMIAH KOMPUTER GRAFIS Vol. 14, No. 1, Juli $2020: 25$ - 36 
Menurut (Puraniwangun 2020) Media Sosial adalah sebuah jembatan komunikasi baik antar personal maupun antar badan atau lembaga dengan menggunakan fasilitas internet.[10]

1) Youtube

Menurut (Cahyono 2019) Youtube adalah media paling strategis, yang membuat konten video untuk menyebarkan informasi sebagai seni berkomunikasi dengan melibatkan para pengguna.[11]

2) Instagram

Menurut (Remaja 2017) Instagram adalah salah satu jenis media sosial yang sangat banyak digunakan remaja pada jaman sekarang.[12]

\section{Metode R\&D}

Menurut (Prasetyo 2014) Research and Development adalah metode penelitian yang digunakan untuk menghasilkan produk tertentu dan menguji keefektifan produk tersebut.[13] Perlu dipahami pula bahwa R\&D merupakan metode penelitian multi tahap bahkan dalam beberapa kasus, penelitian dengan metode ini memakan waktu lebih dari satu tahun, sehingga peneliti perlu untuk lebih terampil dalam merencanakan penelitian ini agar hasil yang diharapkan dapat diperoleh sesuai dengan waktu yang direncanakan. Sesuai dengan namanya, Research \& Developmnet difahami sebagai kegiatan penelitian yang dimulai dengan research dan diteruskan dengan development. Kegiatan research dilakukan untuk mendapatkan informasi tentang kebutuhan pengguna (needs assessment) sedangkan kegiatan development dilakukan untuk menghasilkan perangkat pembelajaran.

Tahapan dalam penelitian dan pengembangan $(R \& D)$ dalam penelitian ini secara operasional mengadopsi model Borg \& Gall yang terdiri dari:

1) Potensi dan Masalah;

2) Mengumpulkan Informasi;

3) Pengembangan Model ;

4) Validasi Model ;

5) Revisi Model ;

6) Uji Coba Model;

7) Revisi Model;

8) Uji Coba Lebih Luas; dan

9) Revisi Model Akhir (Sugiyono, 2008: 298).

Makalah ini akan membahas mengenai beberapa tahapan teknis dalam implementasi R\&D khususnya pada tahap pra penelitian dan paska penelitian. Beberapa hal yang akan dibahas antara lain: studi literatur, pengembangan instrument, penelitian pendahuluan, mengembangkan desain eksperimental dan melakukan uji keefektivan serta efisiensi program yang dikembangkan dalam penelitian.

\section{Tijauan Umum}

Ukm Nok uus berdiri sejak tahun 2009, mekanisme yang dilakukan selama ini dengan memasarkan produk secara konvensional ke outlet-outlet atau menitipkan produk di warungwarung makan, kantin rumah sakit, minimarket, dan kios-kios kecil lainnya. Nok uus adalah owner dari brand "Rempeyek Nok Uus", memiliki 5 karyawan yang membantu dalam proses produksi rempeyek. Rempeyek nok uus memiliki macam-macam varian rasa, antara lain rasa kacang kedelai, teri, dan kacang tanah. Konsumen rempeyek nok uus sampai saat ini udah cukup meluas, nok uus juga menjualkan produknya di supermarket ternama seperti carefour dan transmart.

Untuk pengelolaan produksi di kontrol oleh Ibu Nok Uus dan dibantu juga oleh suami. Remepeyek Nok Uus memiliki Visi dan Misi untuk kemajuan produk mereka. Visinya adalah mewujudkan kualitas yang bernuansa tradisional namun berwawasan Internasional, sedangkan Misinya adalah Mengutamakan kualitas dalam hal pelayanan dan penyajian produk. Dan juga 
mengembangkan inovasi-inovasi dalam produk maupun pelayanan dengan tetap pada koridor tradisional.

Dalam struktur UKM Rempeyek Nok Uus dipimpin oleh owner sendiri yang bernama Ibu Nok Uus dibantu oleh Suami yang bernama Bapak Asep H Syamsudin dan 4 tetangga sebagai rekan kerja. Nok uus mempunyai strategi terhadap produknya, yang diutamakannya adalah dalam kualitas rasa, Rempeyek Nok Uus terkenal dengan kualiatas yang tidak berminyak, gurih, memiliki varian rasa, dan kemasan sangat kekinian, berbeda dengan rempeyek produk lain. Dan Rempeyek Nok Uus mempunyai slogan "REMPEYEK NOK UUS UEEENAAKK KRENYES KRENYES".

Untuk pengelolaan produksi di kontrol oleh Ibu Nok Uus dan dibantu juga oleh suami. Untuk bahan bakunya memakai tepung beras, santan, telor, kemiri, bawang putih, ketumbar, garam, dan penyedap rasa. Rumah tempat tinggal dijadikan sebagai rumah produksi Rempeyek Nok Uus, yang beralamatkan di Kondang Jaya, Kec. Karawang Timur, Kabupaten Karawang, Jawa Barat 41371.

\section{Results and Analysis}

3.1. Metode Penelitian

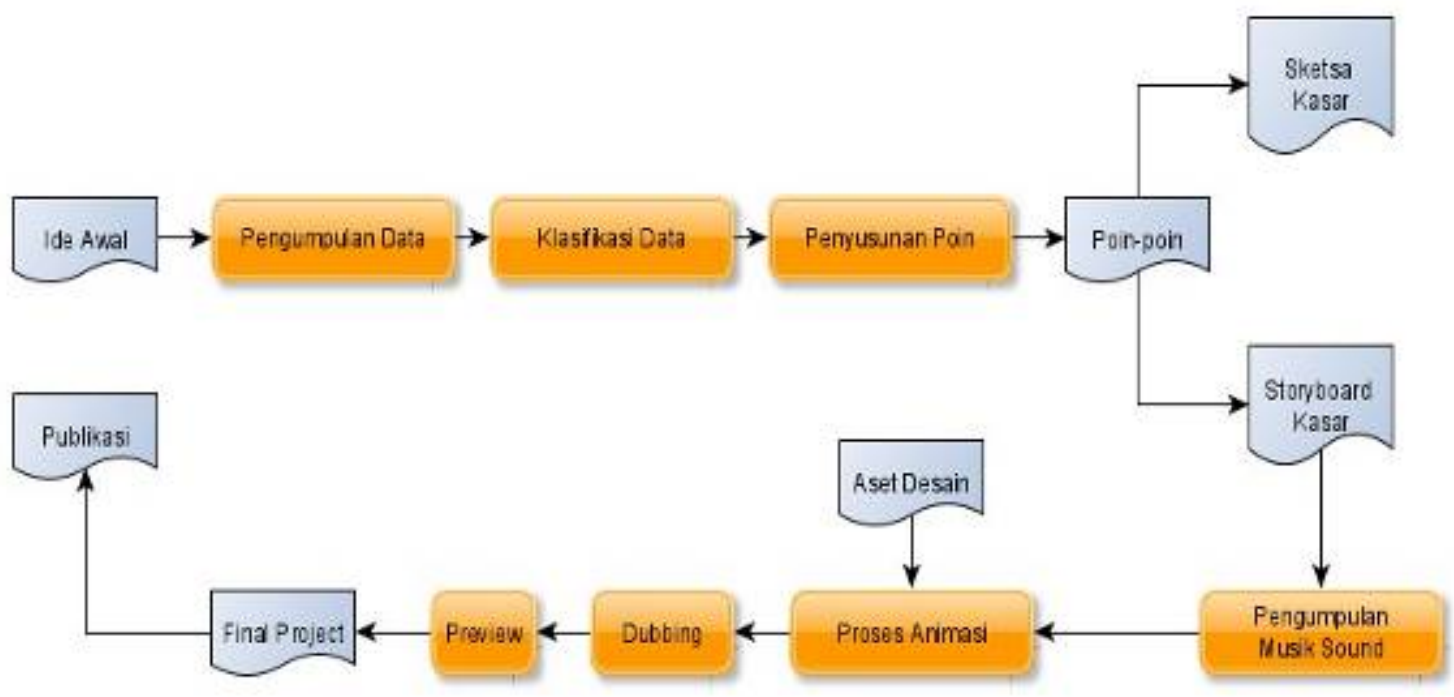

\section{Ide Awal}

Gambar 1. Flowchart Perancang Video

Setelah memahami standar kualitas baik dan standar kerja yang dibutuhkan, sekarang menerapkan proses kerja yang sesuai standar agar menghasilkan produk yang berkualitas baik. Konsep produksi timbul dari pemikiran untuk dituangkan menjadi ide yang aka di implementasikan ke dalam proses produksi, step by step telah terkonsep dengan baik.

\section{Pengumpulan Data}

Untuk mendapatkan data yang diperlukan hal yang harus dilakukan adalah wawancara, observasi, dan dokumentasi. Sehingga bisa mendapatkan konsep yang matang untuk melakukan produksi video, yang acuannya dari informasi-informasi yang didapat ketika observasi dan wawancara.

\section{Klafikasi Data}

Dari data-data yang diperoleh ketika melakukan pengumpulan data, penulis menyeleksi data yang perlu di ambil dan data yang tidak perlu diambil. Hal ini agar hasil produksi video mendapatkan yang lebih maksimal dan terukur.

JURNAL ILMIAH KOMPUTER GRAFIS Vol. 14, No. 1, Juli 2020 : 25 - 36 


\section{Penyusunan Poin}

Penyusunan poin untuk membuat storyboard atau sketsa, agar mendapatkan jalan cerita yang menarik ketika sebelum mengambil gambar atau take video. Penyusunan poin bisa dilakukan dengan membuat sketsa kasar atau storyboard kasar. Pada tahap ini juga ditentukan jenis musik dan sound effect yang mungkin dibutuhkan. Apabila menggunakan voiceover, maka dapat diberi catatan di scene mana saja pembagian voiceovernya.

\section{Pengumpulan Musik Sound}

Memilih musik latar dapat dilakukan dengan mengenali konten videonya. Apakah dibutuhkan suasana yang penuh semangat, suasana tenang, atau suasana menghayati atau mengenang. Semua dapat dipenuhi dengan memilih musik yang tepat. Musik latar dapat di cari dari berbagai penyedia musik dan sound effect, dengan berbagai lisensi baik yang $100 \%$ gratis, harus menyertakan kredit maupun berbayar. Salah satu yang paling praktis adalah Youtube Audiolibrary.

\section{Proses Animasi}

Pada proses ini animasikan objek berdasarkan storyboard yang telah dirancang. Untuk memudahkan proses, kelompokkan scene pada storyboard menjadi beberapa bagian, misalnya bagian pembuka, bagian inti (misalnya dipisah lagi menjadi inti 1, inti 2, dst) dan bagian penutup. Hal ini akan menjadikan proses animasi lebih ringan karena tidak di proses sekaligus, juga memudahkan proses revisi.

\section{Dubbing}

Hal yang perlu dicatat pada produksi voiceover adalah kelengkapan berupa mic atau recorder yang mampu meredam noise, dan dilakukan pada ruangan yang ideal (tidak ada suara). Direkomendasikan memiliki ruangan khusus untuk merekam suara, Dubbing dilakukan pada saat video telah terkompilasi utuh. Dubber melakukan rekaman dengan mempelajari script dan mempelajari scene by scene video yang telah dibuat.

\section{Exporting Final Art (Siap dipublikasikan)}

a. Instagram

Pengaplikasian video untuk menjadi file ready to publish ke berbagai media.

Eksporting video dinamis pada instagram dapat menggunakan ukuran default 1080px (1:1 kotak) dengan maksimal durasi 60detik dan maksimal size yang dapat diterima adalah 4GB dengan frame rate maksimal 30fps.

b. Youtube

Eksporting video dinamis untuk youtube direkomendasikan menggunakan ratio 16:9 dengan kualitas full HD 1080p (1920px x 1080px) atau minimal HD 720p (1280px x 720px) pada rate $29,97 \mathrm{fps}$.

c. Whatsapp

Untuk sharing video di whatshapp, gunakan kualitas video versi medium dan upayakan ukuran maksimal 5MB. File yang dapat diterima dalam sharing video di whatshapp adalah $16 \mathrm{MB}$, tetapi tidak perlu memanfaatkan batas maksimal tersebut agar video dapat diterima user dengan optimal dan nyaman.

Penulis mendapat informasi mengenai keadaan perusahaan terutama mengenai struktur UKM. Pada Bab III telah dijelaskan struktur organisasi UKM Rempeyek Nok Uus. Karena basisnya UKM ini tidak begitu besar, maka UKM tersebut tidak mempunyai struktur organisasi secara detailnya atau yang pasti.

\section{a. Pengenalan Distribusi UKM}


Penulis diberikan informasi tentang saluran distribusi UKM Rempeyek Nok Uus oleh Suami Nok Uus yaitu Bpk Asep H Syamsudin. Pak Asep menjelaskan Proses distribusi produk dari rumah produksi sampai ke konsumen. Saluran distribusinya untuk saat ini hanya menitipkan produk produk ke kantin-kantin Rumah Sakit, warung-warung kecil, dan supermarket (Carefour / Transmart).

\section{b. Tahap Rancangan}

1) Flowchart Pemikiran Pembuatan Video Profile UKM Nok Uus sebagai berikut

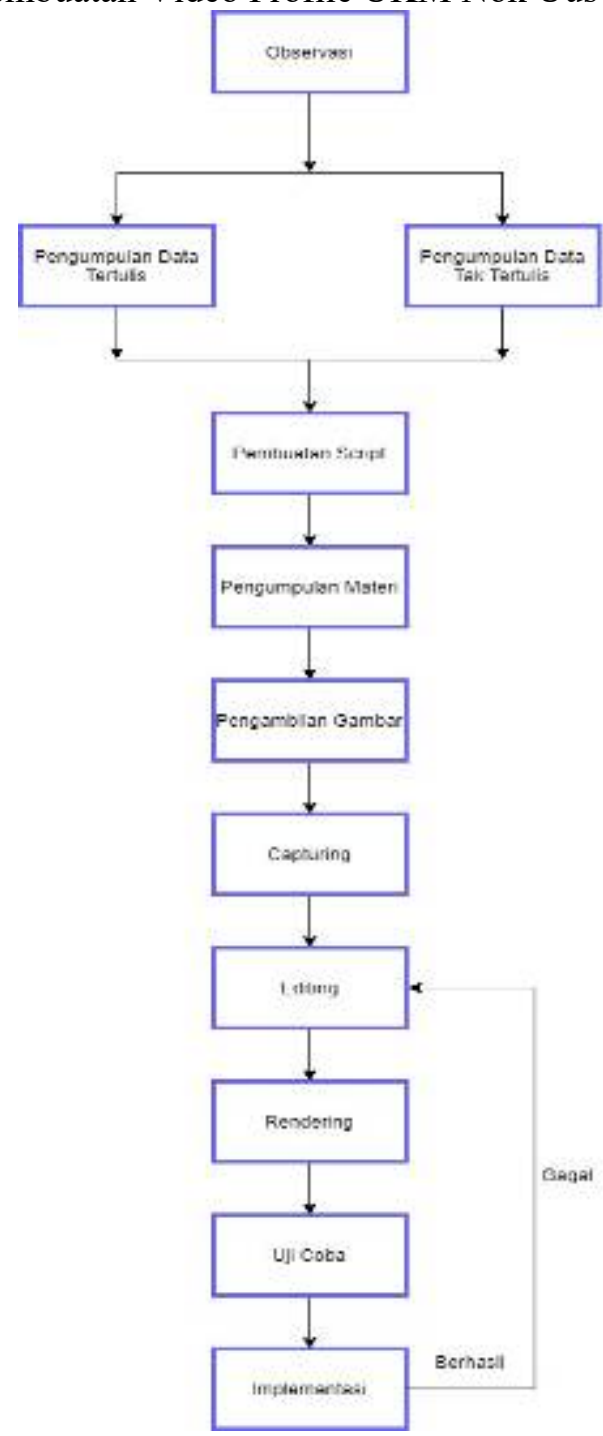

Gambar 2. Flowchart Pembuatan Video

2) Proses Editing

1. Proses Pembuatan Motion Graphic menggunakan Power Point Menurut Sukarno Motion Graphic adalah potongan-potongan media visual berbasis waktu yang menggabungkan film dan desain grafis. Hal tersebut bisa dicapai dengan

JURNAL ILMIAH KOMPUTER GRAFIS Vol. 14, No. 1, Juli $2020: 25$ - 36 
menggabungkan berbagai elemen-elemen seperti animasi 2D dan 3D, video, film, tipografi, ilustrasi, fotografi, dan musik.

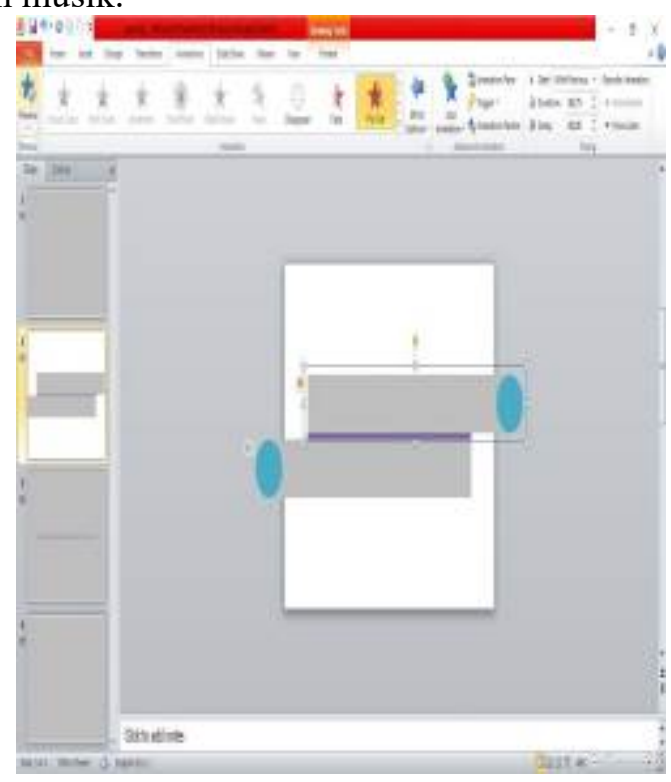

Gambar 3. Pembuatan Motion Graphic

2. Mengurutkan Video Agar mudah proses pengeditan

Pengurutan video dilakukan agar mempermudah menginput video kedalam software adobe premiere Pro CC .

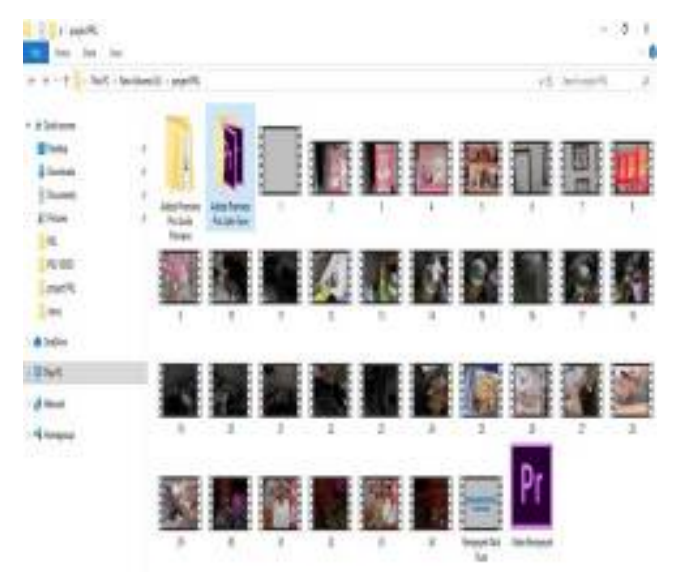

Gambar 4. Proses Pengurutan Video

3. Tampilan Awal Adobe Premiere Pro CC 2017

Berikut adalah tampilan awal dari software Adobe Premiere Pro. 


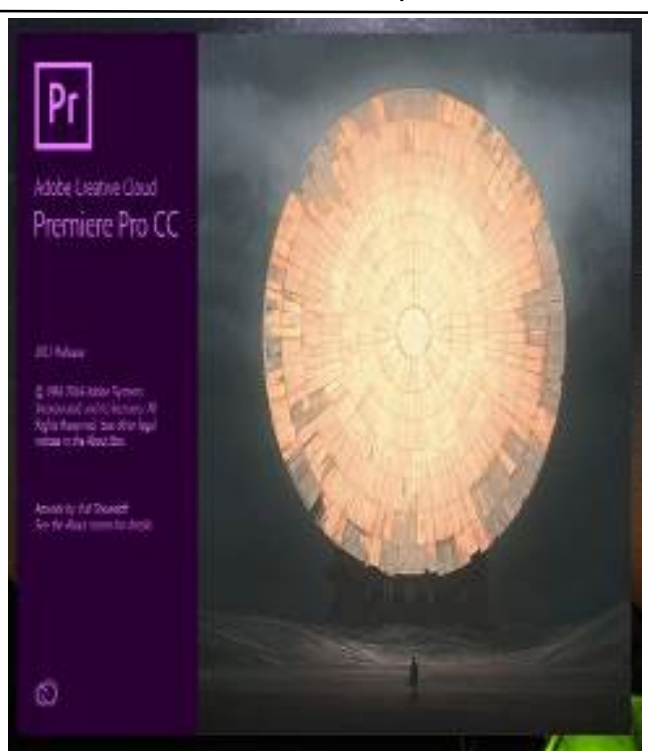

Gambar 5. Tampilan Awal Adobe Premiere Pro CC 2017

4. Proses Editing Video di Adobe Premiere Pro CC 2017

Menurut Franky Cutuhatunewa editing video adalah sebuah proses edit terhadap klip-klip video dari hasil proses shooting, dimana pada proses ini seorang editor memilih atau menyunting gambar dalam bentuk video tersebut dengan cara memotong klip-klip video.

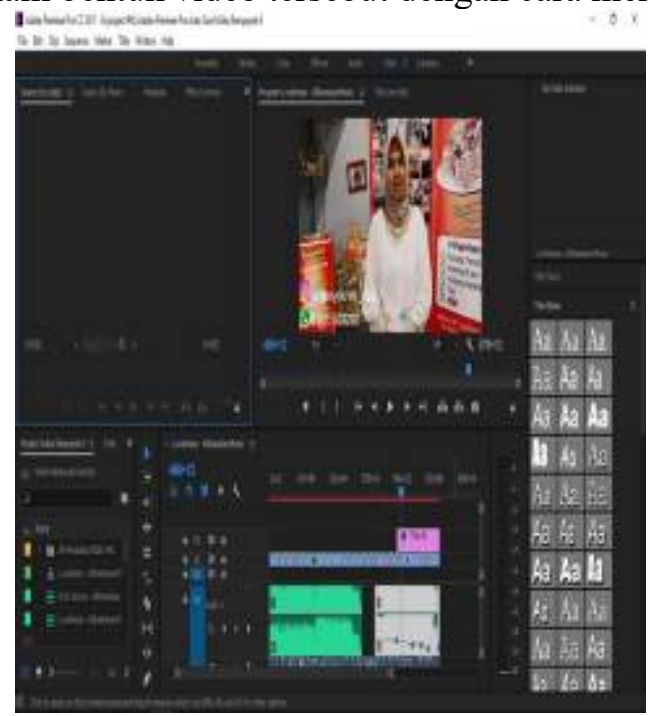

Gambar 6. Proses Editing di Adobe Premiere Pro CC 2017

5. Proses Rendering

Menurut Aditya Proses Rendering adalah proses pengkalkulasian akhir dari keseluruhan proses dalam pembuatan gambar atau animasi 3D. Rendering akan mengkalkulasikan seluruh elemen material, pencayahan, efek, dan lainnya sehingga akan menghasilkan output gambar atau animasi yang realistik.

JURNAL ILMIAH KOMPUTER GRAFIS Vol. 14, No. 1, Juli $2020: 25$ - 36 


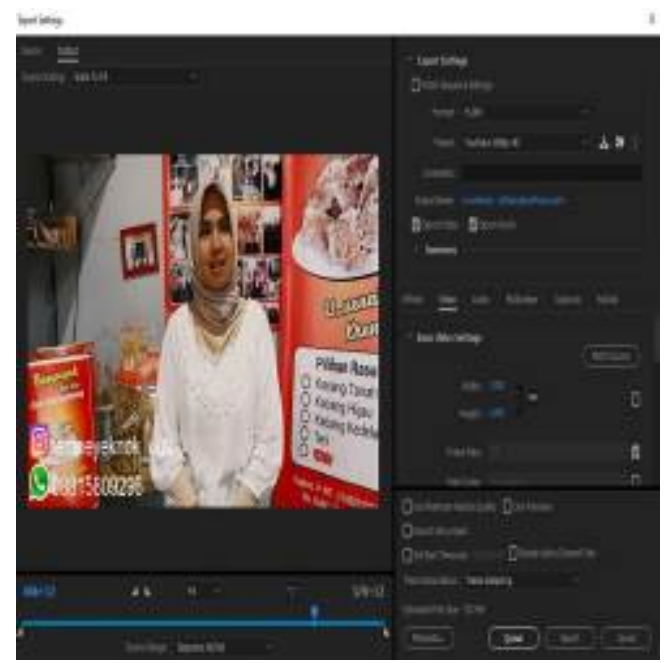

Gambar 7. Proses Rendering

\section{Conclusion}

UKM Rempeyek Nok Uus merupakan ukm yang berada di karawang, memiliki cita rasa yang berbeda dengan produk-produk rempeyek yang lainnya. Rempeyek Nok Uus sudah menjadi khas oleh-oleh karawang dan jajanan atau cemilan daerah karawang.

\subsection{Kesimpulan}

Kelebihan dari UKM Rempeyek Nok Uus ini adalah dengan hasil rempeyek yang tidak berminyak dan rasanya yang sangat gurih. Rempeyek Nok Uus berdiri sejak tahun 2009, namun tidak semua masyarakat tau tentang produk ini. Untuk itu penulis akan memberikan beberapa rekomendasi dengan beberapa permasalahan dalam bagian pemasaran.

\subsection{Saran}

1. Mengoptimalkan digital platform sebagai tempat order produk agar masyarakat mudah untuk memesan.

2. Aktif dalam sosial media terutama instagram dan facebook dalam mengiklankan produk.

3. Ajak selebgram instagram bekerja sama yang sudah mempunyai followers lebih dari $10 \mathrm{~K}$ untuk mempromosikan produk, agar produk dapat diketahui lebih luas lagi di beberapa daerah atau kota.

4. Memberikan harga promo kepada pelanggan, agar dapat menarik perhatian masyarakat lain.

\section{References}

[1] Aris Kurniawan, "Pengertian Strategi - Tingkat, Jenis, Bisnis, Integrasi, Umum, Para Ahli," Gurupendidikan.Co.Id. 2020.

[2] G. Ardiansyah, "Pengertian Strategi Pemasaran," Journal of Chemical Information and Modeling, 2020. .

[3] A. Widayati, "Perilaku Kesehatan (Health Behavior): Aplikasi Teori Perilaku untuk Promosi ... - Aris Widayati - Google Buku," Sanata Dharma University Press. 2019.

[4] A. Arsyad, "pengertian video," materi carego, 2016. .

[5] Y. Fauzi, "MANAJEMEN PEMASARAN PERSPEKTIF MAQASID SYARIAH,” J. Ilm. Ekon. Islam, vol. 1, no. 03, 2015, doi: 10.29040/jiei.v1i03.51.

[6] N. Sugihartini et al., "Pelatihan Video Editing Tingkat Smk Se-Kota Singaraja," J. Widya Laksana, vol. 6, no. 2, 2017.

[7] 2017/BC-F/5199 MUHAMMAD FALAHUNAUFAL, "PERAN DIRECTOR OF PHOTOGRAPHY DALAM VIDEO CLIP 'SNACKERS - SEMUA PERGI DAN HILANG,’” Aug. 2020.

[8] N. Laili Hidayati, "Pengaruh Viral Marketing, Online Consumer Riviews Dan Harga Terhadap Keputusan Pembelian Shopee Di Surabaya,” J. Pendidik. Tata Niaga, vol. 6, no. 3, 2018.

[9] E. Setyowati, "PENGARUH KUALITAS PELAYANAN, HARGA, DAN CITRA MEREK TERHADAP LOYALITAS PELANGGAN DENGAN KEPUASAN PELANGGAN SEBAGAI 
VARIABEL PEMEDIASI,” J. Manaj. Dayasaing, vol. 18, no. 2, 2017, doi: 10.23917/dayasaing.v18i2.4507.

[10] I. A. Purawinangun and M. Yusuf, "GERAKAN LITERASI GENERASI MILENIAL MELALUI MEDIA SOSIAL," Ling. Rima J. Pendidik. Bhs. dan Sastra Indones., vol. 9, no. 1, 2020, doi: 10.31000/lgrm.v9i1.2401.

[11] G. Cahyono and N. Hassani, "YOUTUBE SENI KOMUNIKASI DAKWAH DAN MEDIA PEMBELAJARAN," Al-Hikmah, vol. 13, no. 1, 2019, doi: 10.24260/al-hikmah.v13i1.1316.

[12] D. I. K. Remaja, "Motif

JURNAL ILMIAH KOMPUTER GRAFIS Vol. 14, No. 1, Juli $2020: 25-36$ 